\title{
Obituary
}

\section{Professor Sir Ronald Baskett, O.B.E., B.Sc. London, M.Sc. Reading, Hon.DSc. Belfast, F.R.I.C.}

Ronald Gilbert Baskett ('John' to his family and friends) died on 24 November 1972 at the age of 71, while still Secretary of the Agricultural Research Council. He was born in Colchester on 30 October 1901 and was educated at King Edward VI Grammar School at Chelmsford. His father, Charles Henry Baskett, was the Principal of the College of Science and Art at Chelmsford and a Fellow of the Royal Society of Painter-Etchers and Engravers, and much of his beautiful art work was displayed in John Baskett's home and in his study in the various places where he held office. He graduated in Chemistry at the University College of Reading in 1923 and obtained his M.Sc. in 1930 in Agricultural Chemistry. His early career was devoted to teaching and he started as Demonstrator in Agricultural Chemistry in the University College. In 1924, he became Assistant to the Head of the Chemical and Animal Nutrition Division of the Ministry of Agriculture for Northern Ireland. This was a great step in his life because he played a very important part in the agricultural affairs of Northern Ireland from then onwards. He certainly made a great name for himself in Queen's University at a later date by first becoming Assistant in the Agricultural Chemistry department and later, in 1928, Lecturer in charge. He soon became the Head of the Chemical and Animal Nutrition Division of the Ministry and in 1935 was appointed Professor of Agricultural Chemistry of Queen's University. There is no doubt that this was the point in his career where he started to show his ability as an administrator and as a person who was actively concerned with the affairs of agriculture. The post he held in Northern Ireland as Professor of Agricultural Chemistry at Queen's University was linked to the office of Chief Scientific Officer at the Ministry of Agriculture for Northern Ireland. He was also at this time in the early days of the war Dean of the Faculty of Agriculture of Queen's University. This gave him the opportunity to show his worth and he certainly was greatly respected by everyone concerned in that University. The measure of his contribution in Northern Ireland was later recognized when Queen's University endowed him in July 1963 with the Honorary Degree of Doctor of Science, a welcome and well-deserved distinction for his long service in that University, not only in agricultural matters, but also for his active participation in the affairs of the University. He was regarded by his colleagues as a person who could be trusted to handle the most difficult situations with a minimum of disturbance and this aptitude was of great value to him throughout his subsequent career.

The next important step was his appointment as Agricultural Attaché to the British Embassy in Washington, a post he held with great distinction between 1950 and 1952 and which greatly widened his circle of friends and gave him the opportunity to develop once more his masterly ability to deal with complex and sensitive situations. Sir Ronald always referred to his stay in Washington as a stage in his career where 
he learned more than he gave, a very typical comment and one taken by those who knew him as a token of his subtle honesty.

He came to Shinfield as Director of the National Institute for Research in Dairying in 1959 to succeed Professor Kay. This was a daunting and a challenging task to succeed someone who had for so long reigned over, and built a world-wide reputation for, his Institute and had succeeded so effectively in putting the N.I.R.D. on the highest scientific level. There is no doubt that Sir Ronald was equal to the task and he brought with him his joviality and his friendliness and directed these qualities to the intensification of his predecessor's work. Much of his time was spent in the initial stages in working towards the very successful relationship with the University of Reading. As the person almost solely responsible for bringing the Institute closer to the University, he formulated a model which was later adopted in some measure by other institutes of agricultural research. The experience of his years in the Queen's University of Belfast came very much to his help in establishing the new status of the Institute, which subsequently proved clearly the very great benefits which were to be derived on both sides from such a unification. As a born and intuitive administrator, it was not surprising that he spent a great deal of his efforts in establishing the organization of the Institute on a tidy and effective administrative basis, a fact for which his successors will always be most grateful. In doing so he had never overlooked the scientific needs and the scientific objectives of the Institute of which he was so proud. He immediately gained the respect of the staff and gave dignity to the Institute which, without formality, created an effective and friendly relationship with all his staff and, being a very generous and kind person, he rapidly commanded the trust of all with whom he came into contact.

He also involved himself wholeheartedly in the problems concerning the relations between the Institute and the dairy industry, his work on committees of many different kinds demonstrating the vital need he saw for close contacts with the industry, in which he made a great number of real friends. The Consultative Committee which he formed at the Institute was an earnest effort to establish a meaningful link between the research of the Institute and practice in industry. In all spheres of the industry he attended many meetings concerning the problems affecting the research of the Institute. He was also frequently consulted for his advice by the Agricultural Research Council, where he sat on several important boards and committees and since 1954 was a member of the A.R.C. Technical Committee on Pig Research and its Chairman from 1961 until 1972. His knowledge of the nutritional requirements of animals put him very much in demand for membership of A.R.C. Technical Committees as well as many other Standing Committees and Working Parties. In his later years as Director of the N.I.R.D. he was a member of the Departmental Committee of Inquiry into Recruitment for the Veterinary Profession. Again, he showed his very wide vision in the deliberations of this Committee. In a similar vein he became a member of the Ford Foundation Mission which looked into the organization of agricultural education and research in the West Indies, and his visit was a turning-point in the future of the School of Agriculture of the University of the West Indies.

When he retired from the Institute it was clear that he would not resign himself to an inactive life and to a complete severance from his previous interests. The confidence he had deserved from many organizations ensured an interesting retirement. 
Soon he was called back to serve on various committees of the Agricultural Research Council and to act as adviser in many different capacities. He was a member of Visiting Groups to A.R.C. Institutes, while fulfilling many other useful services to the Council, who were greatly indebted to him for his efforts. His retirement in Northern Ireland gave him the opportunity of rejoining once more the circle of friends he had at Queen's University and it is a clear indication of the appreciation they held for John Baskett that he was once more effectively brought into the University circles. He was never really, in fact, allowed to retire properly and the day soon came, in 1971, when he was invited to take on the Secretaryship of the Agricultural Research Council for one year. This most unusual step for a person retired four years from office was the final mark of the confidence in which he was held. Knowing the difficulties which he was to face, he accepted this challenge as just one more task for which he was called. He was asked by the Council to guide its affairs at the most critical time in its history, during the year when the reorganization of Government research was being formulated. Typically he gave hirnself fully to this task without any consideration for himself or for his private life. His agility in guiding committees through difficult problems was once more conspicuous. He was, as before, greatly concerned with everybody's welfare and was proud to lead the Council towards a new and hopeful future. Most unfortunately he was taken ill just before the annual Directors' Conference, at which he was to report the results of his lengthy labours. The foundation of the work had been done, the planning of the future had been achieved and it is sad that he never saw the day when this planning would, in fact, start bearing fruit.

Our greatest sympathy and understanding go to his wife, Shirley, whose encouragement was never-failing, whatever the challenge. 